\title{
EXPERIMENTAL STUDY OF NON- AUTOCLAVED LIGHTWEIGHT CONCRETE PREPARED BY BAGASSE ASH
}

\author{
NISHANT KUMAR ${ }^{1} \&$ SUNEHA DHIMAN ${ }^{2}$ \\ ${ }^{1}$ Post Graduate Student, Department of Civil Engineering, Chandigarh University, Mohali, Punjab, 140413, India \\ ${ }^{2}$ Assistant Professor, Department of Civil Engineering, Chandigarh University, Mohali, Punjab, 140413, India
}

\begin{abstract}
This experimental study is mainly focused on the production of lightweight concrete using bagasse ash as the partial replacement of the cement in the non autoclaved concrete. The dead load of the building also consists of a load of partition walls and normal mortars. Bagasse Ash has a low density which also reduces the weight of concrete. The introduction of bagasse ash makes increment in compressive strength by $10 \%$ and split tensile Strength by $10.5 \%$. it also decreases the cost of lightweight concrete by $12 \%$. The prepared concrete has 20 percent more water absorption but $5 \%$ lesser dense.

KEYWORDS: Aluminium Powder, Lightweight Concrete, Non-Autoclaved, Bagasse Ash
\end{abstract}

Received: Jun 06, 2020; Accepted: Jun 26, 2020; Published: Sep 22, 2020; Paper Id.: IJMPERDJUN20201383

\section{INTRODUCTION}

The primary structural material utilized in concrete applied for different structure components, both for auxiliary and non-basic, just as for building components. Concrete has a few points of interest, for example, simple to set up, high compressive quality, customizable quality, and locally accessible material. In any case, concrete likewise has a weakness as far as its weight. This is a significant burden when it is applied to tremor inclined regions like Indonesia. Lightweight frothed concrete is an elective structure material to diminish the danger of building harm because of seismic tremor catastrophe. Non autoclaved circulated air through cement (AAC) as a structural material has been mechanically delivered since the start of the twentieth century. It is a type of cement with lightweight, got by consistently dispersed, shut air bubbles. Since AAC ordinarily has one-6th to $33 \%$ the thickness of traditional cement, and about a similar proportion of compressive quality, it is valuable for cladding and infills, and forbearing divider segments of low-to-medium-ascent structures. Besides, because its warm conductivity is one-6th or not as much as that of solid, it can give financially savvy structure arrangements when utilized in low-vitality structures. The material has incredible fire rating properties, and its imperviousness to fire is marginally longer than that of traditional cement of a similar thickness. It isn't vulnerable to form development, and as a result of its inner porosity, it has an exceptionally low solid transmission and is acoustically extremely powerful for a material of its weight. Lightweight frothed concrete is made by presenting air through the exclusive froth procedure to control the thickness of the solid. The thickness of frothed solid extents from 300 to $1800 \mathrm{~kg} / \mathrm{m} 3$, which is fundamentally lower than that of ordinary cement $(2400 \mathrm{~kg} / \mathrm{m} 3)$. Impervious to disappointment because of bacterial, creepy crawly and fire harms. Cell concrete (or circulated air through cement or froth concrete) in which air-voids are entangled in the mortar lattice by methods for a reasonable frothing specialist is created from concrete, lime, silica sand, and once in awhile pozzolanic material. In light of the strategy for pore development, it is characterized into three gatherings: 
Air-entraining technique (gas concrete - utilizing compound response in glue for gas creation), frothing technique (frothed concrete - bringing air into the glue with including bubble stabilizer) and joined strategy (bringing air into the glue utilizing concoction response and balancing out it with gas stabilizer). Because of the relieving temperature, cell cement can be separated into two gatherings: one that is restored at surrounding or marginally raised temperatures, and the difference comprises precast brickwork items that are non autoclaved at a temperature fundamentally higher than $100 \mathrm{C}$ in a pressurized and steam warmed condition. The pore framework in the concrete-based material is routinely delegated gel pores, slender pores, and macropores because of intentionally entrained air, and macropores because of lacking compaction. Contrasted with gel pores, fine pores and other huge pores are liable for any decrease in the quality. The kind of pores can be recognized by examination techniques, for example, nitrogen gas assimilation, mercury porosimetry, optical microscopy with picture handling and X-beam registered tomography with picture preparation. The pore arrangement of autoclaved circulated air through cement is delegated (i) fake air pores, intercluster and interparticle pores, (ii) macropores framed because of the development of the mass brought about by air circulation and micropores which show up in the dividers between the macropores and (iii) smaller scale vessels $(50 \mathrm{~nm}$ to $50 \mathrm{~lm}$ ) and counterfeit air pores $(>50 \mathrm{~lm})$ ). Circulated air through cement is generally comprised of lime, concrete, gypsum, and sand (or pozzolanic materials) with hints of aluminum powder as a pore-shaping specialist. The aluminum responds with lime, which discharges hydrogen gas and structures a lot of little air pockets conveyed consistently in the framework $[9,10]$. After the set, all in all, circulated air through cement was cut into exact dimensional units and afterward restored in an autoclave where the best fix pressure is 1.0-1.2 MPa for 5-8 $\mathrm{h}$. Contrasted and the conventional autoclaved circulated air through cement (AAC), non-autoclaved circulated air through cement (NAAC) has a considerable bit of leeway in encouraging the assembling procedure and diminishing the expense of items. During the NAAC creation, steam restoring was directed lower than $100 \mathrm{C}$ for 8-24 $\mathrm{h}$ in the wake of being cut. Along these lines, the NAAC has the element of security in the item process with low vitality utilization contrasted and AAC. In most worldwide markets, AAC is fabricated and showcased as a brickwork unit. It can frequently be utilized to substitute different types of stonework material, but since the material is solid, yet lightweight, it is regularly utilized in a thickness that is a lot more noteworthy than for different materials. Also, AAC can be utilized to make daintily fortified story stature components or all the more intensely strengthened components for floorboards, rooftop boards, divider boards, lintels, pillars, and other exceptional shapes. These components can be utilized in an assortment of utilizations, including private, business, and modern development. Strengthened divider boards can be utilized as cladding frameworks just as burden-bearing and non-load-bearing outside and inside divider frameworks. Fortified floor and rooftop boards can be effectively used to give the flat stomach framework while supporting the important gravity loads. One of the key properties of AAC fabricate is the adaptability in the process as far as item attributes and item sizes. Therefore, there are numerous conceivable various organizations in which the items can be produced.

\section{METHODOLOGY}

For the study of lightweight concrete, the various proportions of sand and cement with a water-cement ratio of 0.55 is taken for the considerations. And results are derived on the basis of compressive strength, split tensile strength, water absorption, and cost per cubic meter 
Table 1:Content of Light Weight Concrete with Different Proportions of Cement and Sand

\begin{tabular}{|c|c|c|c|c|c|}
\hline Mix Designation & $\begin{array}{c}\text { Ratio of Cement } \\
\text { and Sand }\end{array}$ & $\begin{array}{c}\text { Water Cement } \\
\text { Ratio }\end{array}$ & Cement $\mathrm{Kg} / \mathrm{m}^{3}$ & Sand $\mathrm{Kg} / \mathrm{m}^{3}$ & Water $\mathrm{Kg} / \mathrm{m}^{3}$ \\
\hline N1 & $1: 1$ & 0.55 & 625.000 & 625.000 & 343.750 \\
\hline N2 & $1: 2$ & 0.55 & 416.667 & 833.333 & 229.167 \\
\hline N3 & $1: 3$ & 0.55 & 312.500 & 937.500 & 171.875 \\
\hline N4 & $1: 4$ & 0.55 & 250.000 & 1000.000 & 137.500 \\
\hline N5 & $1: 5$ & 0.55 & 208.333 & 1041.667 & 114.583 \\
\hline N6 & $1: 6$ & 0.55 & 178.571 & 1071.429 & 98.214 \\
\hline N7 & $2: 1$ & 0.55 & 833.333 & 416.667 & 458.333 \\
\hline N8 & $2: 3$ & 0.55 & 500.000 & 750.000 & 275.000 \\
\hline N9 & $2: 5$ & 0.55 & 357.143 & 892.857 & 196.429 \\
\hline
\end{tabular}

After selecting the proper ratio, the mix was tested with the water-cement ratio of $0.45,0.5,0.6$, and 0.65 . because lightweight concrete needs more water to react with the aluminum to initiate the aeration process

Table 2: Content of Light Weight Concrete with Different Water Cement Ratios

\begin{tabular}{|c|c|c|c|c|c|}
\hline $\begin{array}{c}\text { Mix } \\
\text { Designation }\end{array}$ & $\begin{array}{c}\text { Ratio of Cement and } \\
\text { Sand }\end{array}$ & $\begin{array}{c}\text { Water } \\
\text { Cement Ratio }\end{array}$ & Cement $\mathrm{Kg} / \mathrm{m}^{3}$ & Sand $\mathrm{Kg} / \mathrm{m}^{3}$ & Water $\mathrm{Kg} / \mathrm{m}^{3}$ \\
\hline $\mathrm{N} 3$ & $1: 3$ & 0.55 & 312.500 & 937.500 & 171.875 \\
\hline N10 & $1: 3$ & 0.45 & 312.500 & 937.500 & 140.625 \\
\hline N11 & $1: 3$ & 0.5 & 312.500 & 937.500 & 156.250 \\
\hline N12 & $1: 3$ & 0.6 & 312.500 & 937.500 & 187.500 \\
\hline N13 & $1: 3$ & 0.65 & 312.500 & 937.500 & 203.125 \\
\hline
\end{tabular}

For non-autoclaved aerated concrete, the design mix quantities should be reduced to $60 \%$, and the dosage of alumina powder is to be tested. The dosage of alumina powder is $0.1 \%, 0.2 \%, 0.3 \%$ and $0.4 \%$. alumina powder on reaction with water produces air which helps to produce aerated concrete when mixed with water. So the different addition of alumina is tested.

Table 3: Content of Light Weight Concrete with Different Dosage of Alumina Powder

\begin{tabular}{|c|c|c|c|c|c|c|c|}
\hline $\begin{array}{c}\text { Mix } \\
\text { Designation }\end{array}$ & $\begin{array}{c}\text { The Ratio of } \\
\text { Cement and Sand }\end{array}$ & $\begin{array}{c}\text { Water Cement } \\
\text { Ratio }\end{array}$ & Cement & Sand & Water & \multicolumn{2}{|c|}{$\begin{array}{c}\text { Aluminum } \\
\text { Dosage }\end{array}$} \\
\hline N3A0 & $1: 3$ & 0.55 & 187.500 & 562.500 & 103.125 & 0 & 0 \\
\hline N3A1 & $1: 3$ & 0.55 & 187.500 & 562.500 & 103.125 & $0.10 \%$ & 0.187 \\
\hline N3A2 & $1: 3$ & 0.55 & 187.500 & 562.500 & 103.125 & $0.20 \%$ & 0.374 \\
\hline N3A3 & $1: 3$ & 0.55 & 187.500 & 562.500 & 103.125 & $0.30 \%$ & 0.561 \\
\hline N3A4 & $1: 3$ & 0.55 & 187.500 & 562.500 & 103.125 & $0.40 \%$ & 0.748 \\
\hline
\end{tabular}

As per the experimental study the bagasse ash to be introduced in the composite mix hence it contents pozzolanic properties it will help reduce environmental waste and emission of $\mathrm{CO}_{2}$ from the concrete.

Table 4: Content of Light Weight Concrete with Different Proportions of Bagasse Ash

\begin{tabular}{|c|c|c|c|c|c|c|c|}
\hline Mix designation & Ratio of cement and sand & Water cement ratio & Cement & Sand & \multicolumn{2}{|c|}{ Water } & \multicolumn{2}{c|}{ Bagasse ash } \\
\hline & & & $\mathrm{Kg} / \mathrm{m}^{3}$ & $\mathrm{Kg} / \mathrm{m}^{3}$ & $\mathrm{Kg} / \mathrm{m}^{3}$ & $\%$ & $\mathrm{Kg} / \mathrm{m}^{3}$ \\
\hline N3A3 & $1: 3$ & 0.55 & 187.500 & 562.500 & 103.125 & 0 & 0.000 \\
\hline N3B4 & $1: 3$ & 0.55 & 180.000 & 562.500 & 103.125 & 4 & 7.500 \\
\hline N3B8 & $1: 3$ & 0.55 & 172.500 & 562.500 & 103.125 & 8 & 15.000 \\
\hline N3B12 & $1: 3$ & 0.55 & 165.000 & 562.500 & 103.125 & 12 & 22.500 \\
\hline N3B16 & $1: 3$ & 0.55 & 157.500 & 562.500 & 103.125 & 16 & 30.000 \\
\hline N3B20 & $1: 3$ & 0.55 & 150.000 & 562.500 & 103.125 & 20 & 37.500 \\
\hline N3B24 & $1: 3$ & 0.55 & 140.625 & 562.500 & 103.125 & 24 & 46.875 \\
\hline
\end{tabular}




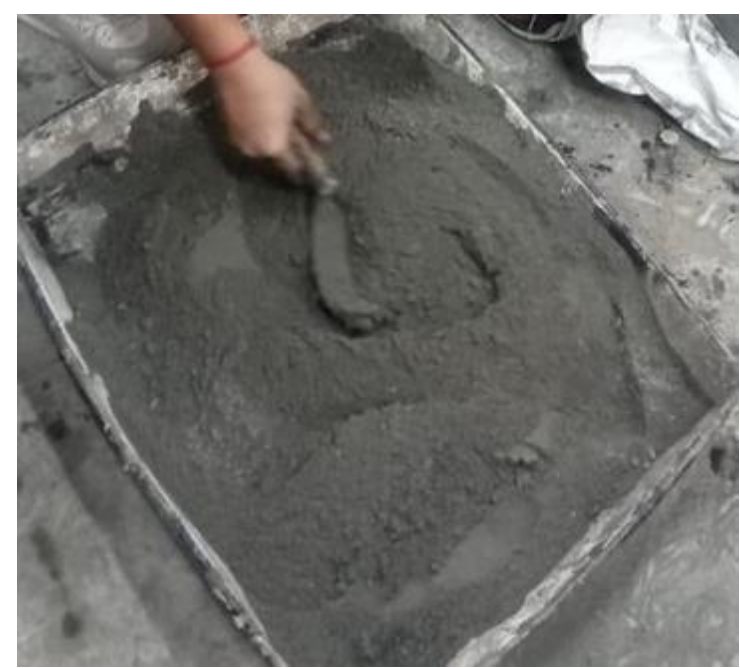

Figure 1: Dry Mix of Light Weight Concrete.

\section{RESULTS}

Table 5: Results of Light Weight Concrete with Different Proportions of Cement and Sand

\begin{tabular}{|c|c|c|c|c|c|c|}
\hline $\begin{array}{c}\text { Mix } \\
\text { Designation }\end{array}$ & $\begin{array}{c}\text { Ratio of Cement } \\
\text { and Sand }\end{array}$ & $\begin{array}{c}\text { Compressive } \\
\text { Strength }\end{array}$ & $\begin{array}{c}\text { Split Tensile } \\
\text { Strength }\end{array}$ & $\begin{array}{c}\text { Water } \\
\text { Absorption }\end{array}$ & Cost & Density \\
\hline N1 & $1: 1$ & 4.740 & 1.524 & 190 & 5937.5 & 1406 \\
\hline N2 & $1: 2$ & 4.400 & 1.468 & 210 & 4583.3 & 1476 \\
\hline N3 & $1: 3$ & 4.000 & 1.400 & 225 & 3906.3 & 1525 \\
\hline N4 & $1: 4$ & 3.500 & 1.310 & 235 & 3500.0 & 1570 \\
\hline N5 & $1: 5$ & 2.900 & 1.192 & 247 & 3229.2 & 1593 \\
\hline N6 & $1: 6$ & 2.400 & 1.084 & 263 & 3035.7 & 1608 \\
\hline N7 & $2: 1$ & 5.200 & 1.596 & 150 & 7291.7 & 1650 \\
\hline N8 & $2: 3$ & 4.500 & 1.485 & 202 & 5125.0 & 1450 \\
\hline N9 & $2: 5$ & 4.250 & 1.443 & 217 & 4196.4 & 1500 \\
\hline
\end{tabular}

In the experimental study of various ratios, 1:3 is found to be very effective in terms of strength, cost, density, and water absorption. The ratio 1:1,1:2,2:1 and 2:3 have higher cement content which has two problems, first is the heat of hydration as the higher the cement content higher will be the heat of hydration .second economy higher cement content is not an economic friendly. As the cement content increases the density of concrete increases. As the cement content increases the pores in the concrete fills which increase the strength of concrete but decreases the water absorption.

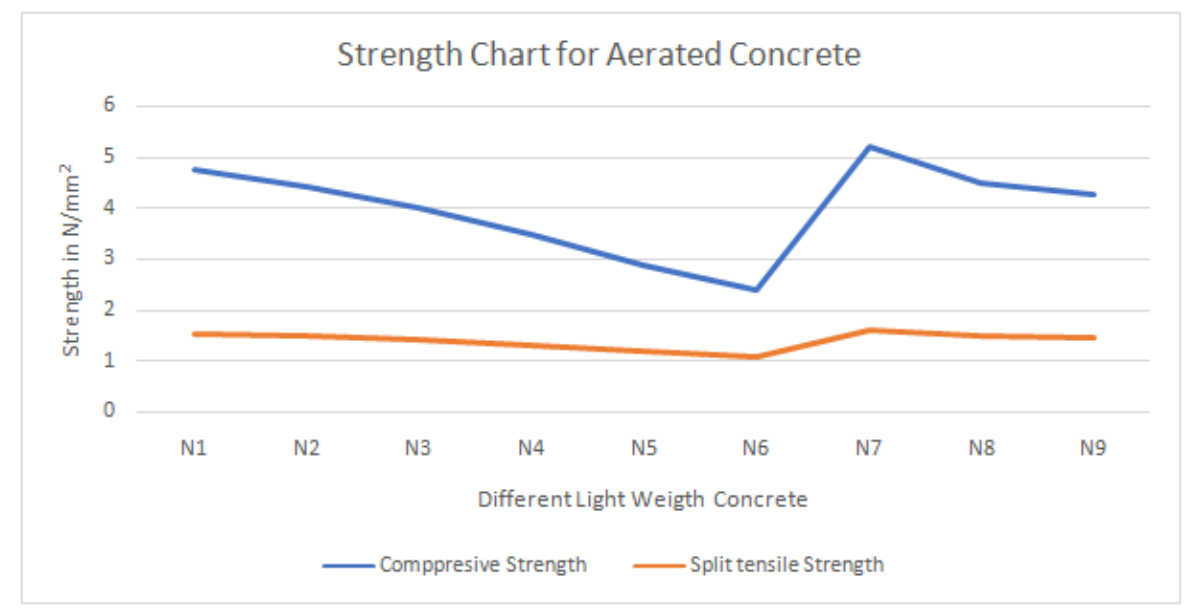

Figure 2: Strength Chart for Aerated Concrete. 


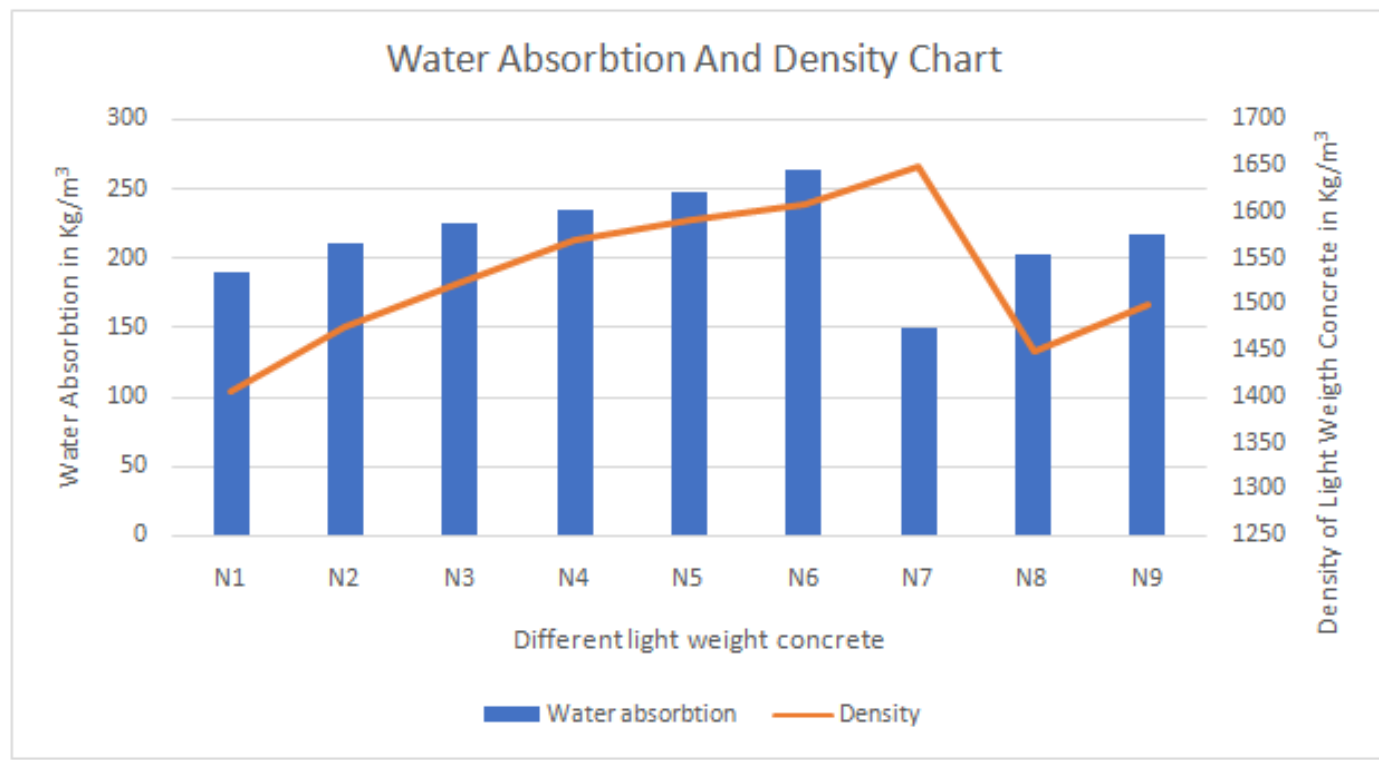

Figure 3: Water Absorption and Density for Aerated Mix.

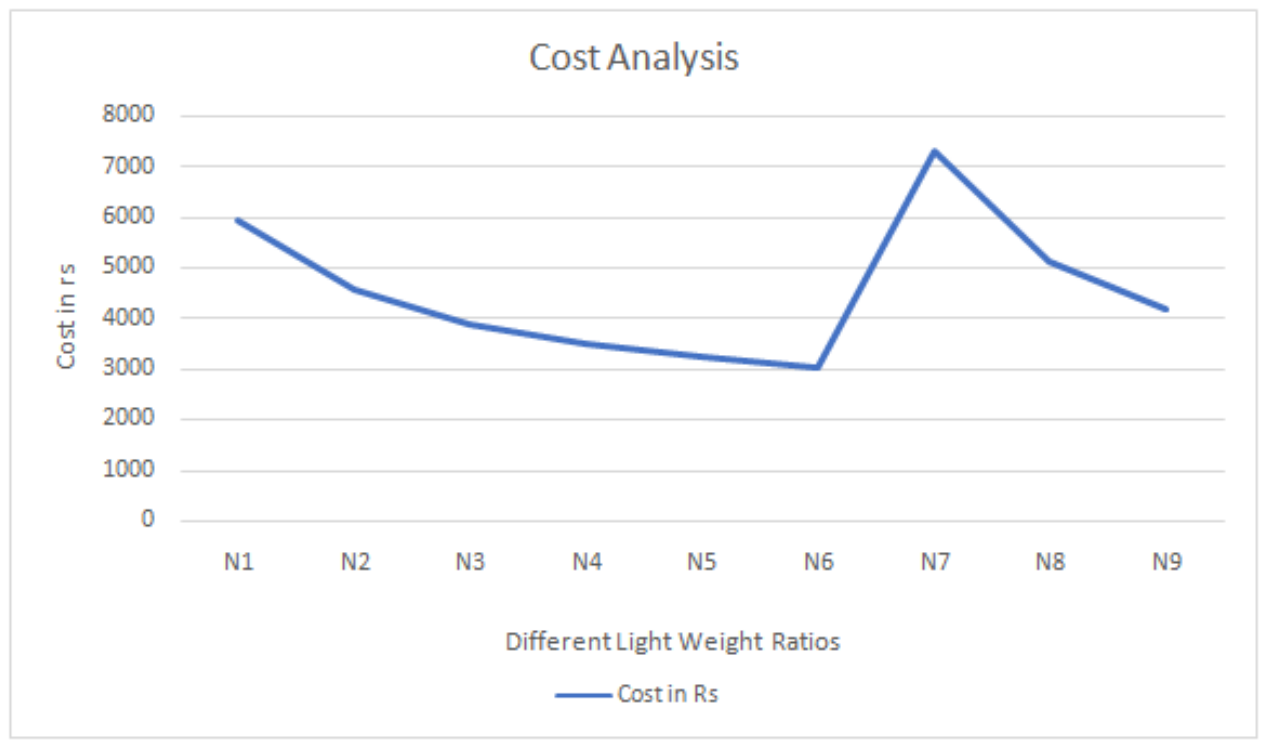

Figure 4: Cost Analysis for Aerated Mix.

Table 6: Results of Light Weight Concrete with Different Water-Cement Ratios

\begin{tabular}{|c|c|c|c|c|c|c|}
\hline $\begin{array}{c}\text { Mix } \\
\text { Designation }\end{array}$ & $\begin{array}{c}\text { Water Cement } \\
\text { Ratio }\end{array}$ & $\begin{array}{c}\text { Compressive } \\
\text { Strength }\end{array}$ & $\begin{array}{c}\text { Split Tensile } \\
\text { Strength }\end{array}$ & $\begin{array}{c}\text { Water } \\
\text { Absorption }\end{array}$ & Cost & Density \\
\hline & & $\mathrm{N} / \mathrm{m}^{2}$ & $\mathrm{~N} / \mathrm{m}^{2}$ & & & $\mathrm{Kg} / \mathrm{m}^{3}$ \\
\hline N3W0 & 0.55 & 4.0 & 1.400 & 225 & 3906.3 & 1525 \\
\hline N3W1 & 0.45 & 3.5 & 1.310 & 235 & 3906.3 & 1523 \\
\hline N3W2 & 0.5 & 3.7 & 1.346 & 230 & 3906.3 & 1520 \\
\hline N3W3 & 0.6 & 3.9 & 1.382 & 225 & 3906.3 & 1532 \\
\hline N3W4 & 0.65 & 3.8 & 1.365 & 217 & 3906.3 & 1538 \\
\hline
\end{tabular}

The experiment shows that at w/c ratio 0.55 gives optimum results in terms of strength. As the water content in concrete increases, the water demand negligibly changes due to less formation of the heat of hydration and cement paste with extra water fills the pores in the concrete so it also absorbs less water means changing the water content does not affect the water absorption of concrete. But the water content makes a negligible effect on the density of concrete. 


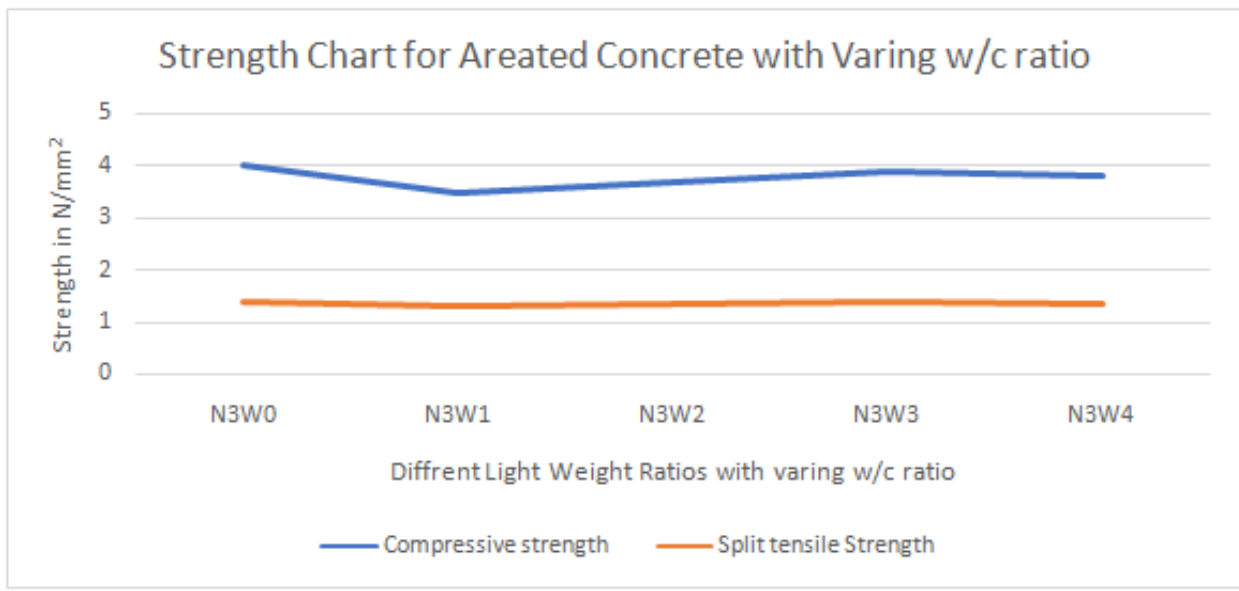

Figure 5: Strength Chart for Aerated Concrete with different Water Cement Ratios.

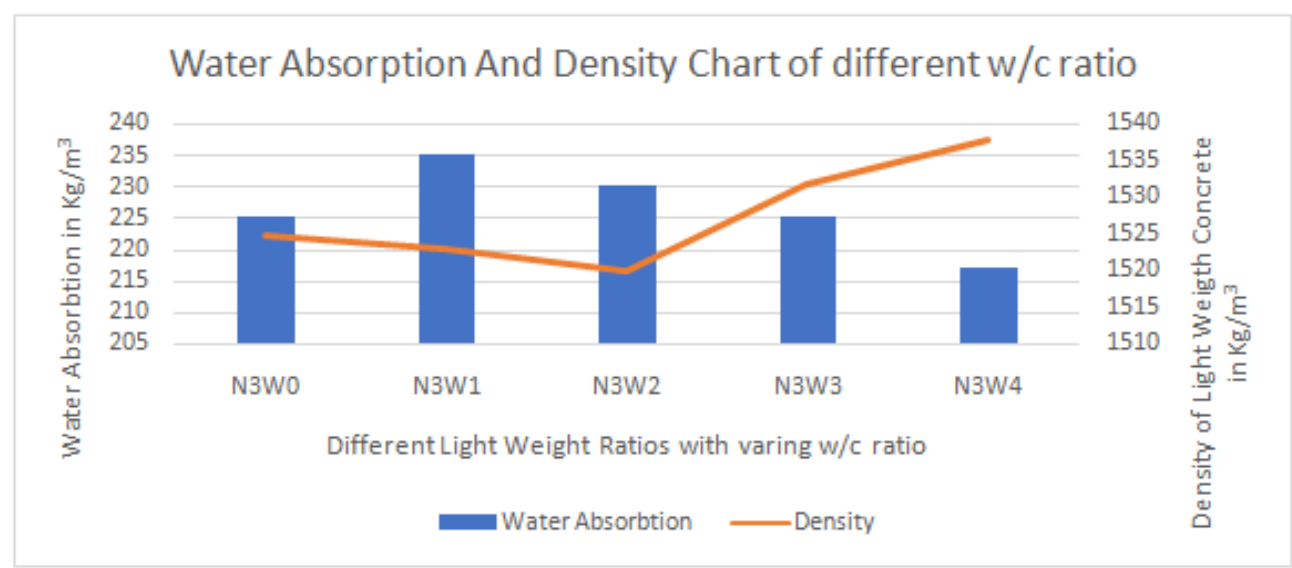

Figure 6: Water Absorption and Density Chart of Different w/c Ratio.

Table 7: Results of Light Weight Concrete with Different Dosage of Alumina Powder

\begin{tabular}{|c|c|c|c|c|c|}
\hline $\begin{array}{c}\text { Mix } \\
\text { Designation }\end{array}$ & $\begin{array}{c}\text { Alumina } \\
\text { Powder Dosage }\end{array}$ & $\begin{array}{c}\text { Water } \\
\text { Cement Ratio }\end{array}$ & $\begin{array}{c}\text { Dry Volume of } \\
\text { Material Taken }\end{array}$ & $\begin{array}{c}\text { Volume After } \\
\text { B24 hrs }\end{array}$ & $\begin{array}{c}\text { Increase in Cost due } \\
\text { to Alumina Powder }\end{array}$ \\
\hline N3A0 & 0 & 0.55 & $60 \%$ & $60 \%$ & 0 \\
\hline N3A1 & $0.10 \%$ & 0.55 & $60 \%$ & $75 \%$ & 140.25 \\
\hline N3A2 & $0.20 \%$ & 0.55 & $60 \%$ & $92 \%$ & 280.5 \\
\hline N3A3 & $0.30 \%$ & 0.55 & $60 \%$ & $102 \%$ & 420.75 \\
\hline N3A4 & $0.40 \%$ & 0.55 & $60 \%$ & $120 \%$ & 561 \\
\hline
\end{tabular}

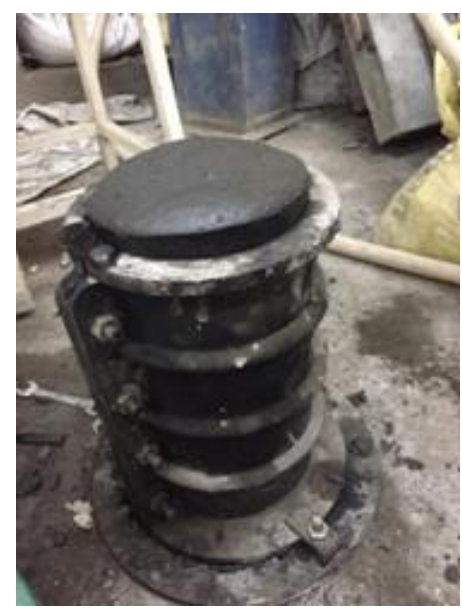

Figure 7: Mix MN3A4 with 120\% Casting Volume. 


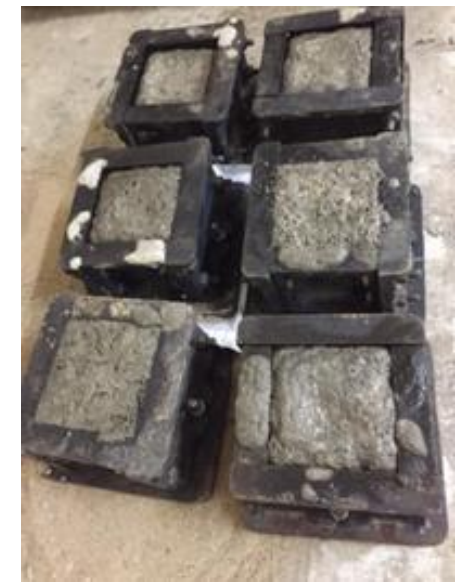

Figure 8: Mix NM3A0 with $100 \%$ Casting Volume.

Alumina powder on reaction with water forms air bubbles which create pores in the concrete so different proportions are tried to check the exact dosage of the alumina powder for the formation of lightweight concrete.

Table 8: Results of Light Weight Concrete with Different Proportions of Bagasse Ash

\begin{tabular}{|c|c|c|c|c|c|c|c|}
\hline $\begin{array}{c}\text { Mix } \\
\text { designation }\end{array}$ & $\begin{array}{c}\text { Ratio of } \\
\text { cement } \\
\text { and } \\
\text { sand }\end{array}$ & $\begin{array}{c}\text { Water } \\
\text { Cement } \\
\text { Ratio }\end{array}$ & $\begin{array}{l}\text { Compressive } \\
\text { Strength }\end{array}$ & $\begin{array}{c}\text { Split } \\
\text { Tensile } \\
\text { Strength }\end{array}$ & $\begin{array}{c}\text { Water } \\
\text { Absorption }\end{array}$ & $\begin{array}{l}\text { Cost (Excluding } \\
\text { the cost of } \\
\text { alumina powder } \\
\text { which is } 750 \mathrm{rs} \\
\text { per } \mathrm{kg} \text { ) }\end{array}$ & Density \\
\hline & & & $\mathrm{N} / \mathrm{m}^{2}$ & $\mathrm{~N} / \mathrm{m}^{2}$ & $\mathrm{Kg} / \mathrm{m}^{3}$ & $\begin{array}{l}\mathrm{RS}(\text { main }+\mathrm{Al} \\
\text { Cost ) }\end{array}$ & $\mathrm{Kg} / \mathrm{m}^{3}$ \\
\hline N3A3 & $1: 3$ & 0.55 & 3.2 & 1.400 & 225 & $2343.8+420$ & 1290 \\
\hline N3B4 & $1: 3$ & 0.55 & 3.3 & 1.435 & 230 & $2283.8+420$ & 1281 \\
\hline N3B8 & $1: 3$ & 0.55 & 3.8 & 1.501 & 245 & $2223.8+420$ & 1250 \\
\hline N3B12 & $1: 3$ & 0.55 & 4.1 & 1.534 & 263 & $2163.8+420$ & 1235 \\
\hline N3B16 & $1: 3$ & 0.55 & 4.3 & 1.550 & 270 & $2103.8+420$ & 1220 \\
\hline N3B20 & $1: 3$ & 0.55 & 3.7 & 1.501 & 290 & $2043.8+420$ & 1150 \\
\hline N3B24 & $1: 3$ & 0.55 & 3.6 & 1.382 & 350 & $1968.8+420$ & 1050 \\
\hline
\end{tabular}

An increase in bagasse ash content increases the strength parameters due to its pozzolanic actions but it also increases the water absorption capacity of concrete because bagasse ash is water-binding ash and it easily absorbs water. Use of bagasse ash can decrease the density of concrete i.e. reduction in weight and use of bagasse ash can result in the reduction in cost also.

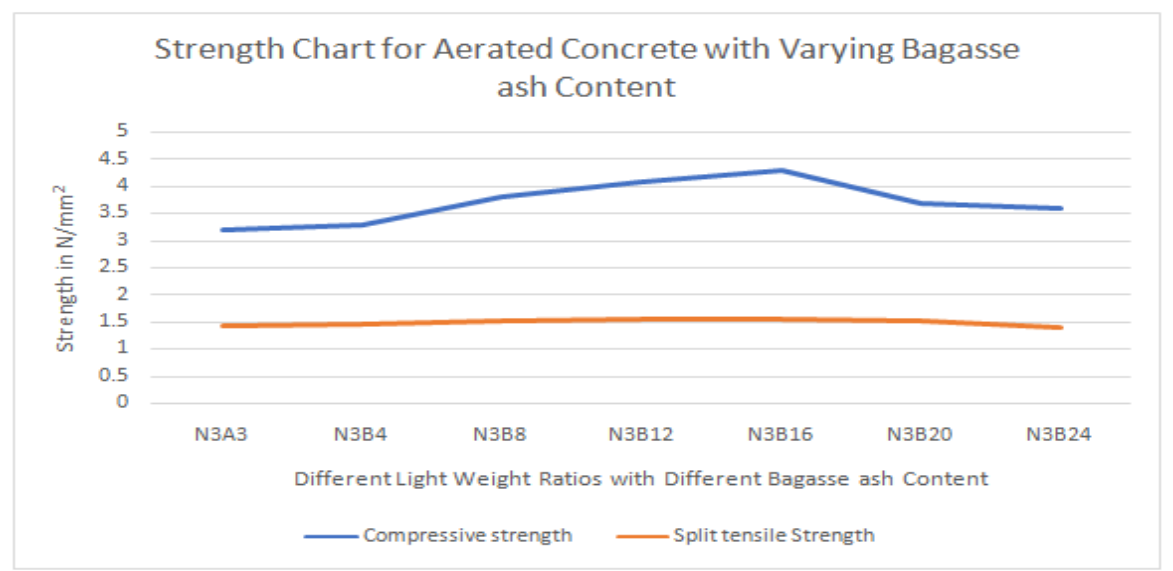

Figure 9: Strength Chart for Aerated Concrete with Varying Bagasse Ash Content. 


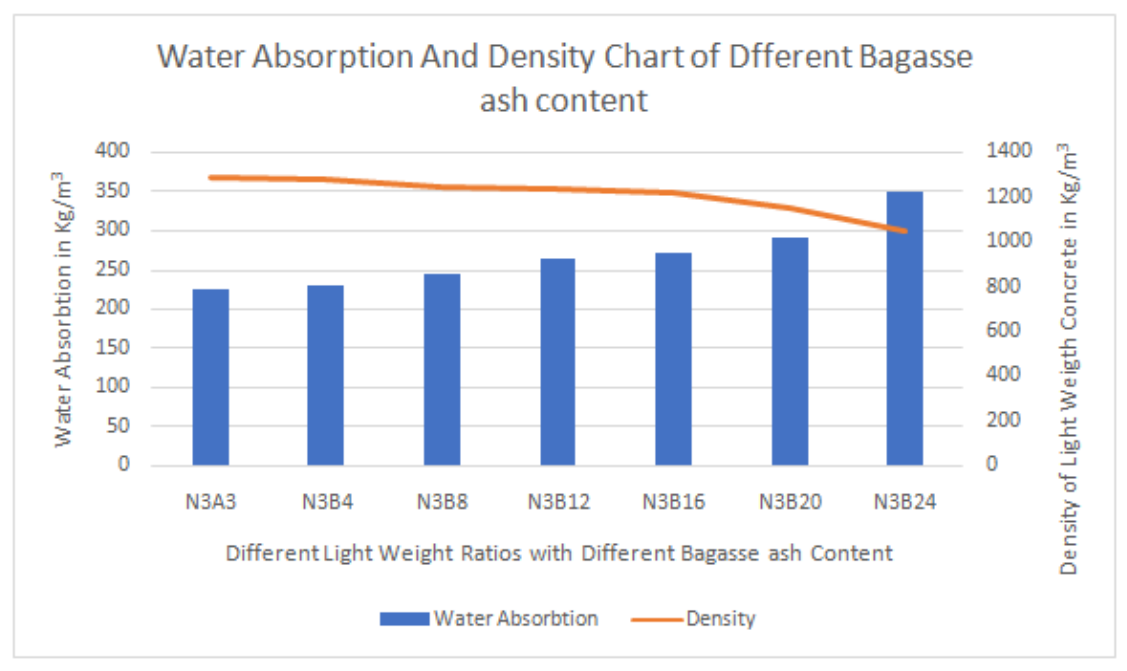

Figure 10: Water Absorption and Density Chart of Different Bagasse Ash Content.

\section{CONCLUSIONS}

- Bagasse ash can be easily replaced cement up to $16 \%$ due to its pozzolanic action

- For the particular ratio, bagasse ash can reduce the cost of lightweight concrete up to12\%.

- Bagasse ash also reduces the weight of concrete up to $6 \%$

- An increase in the strength due to bagasse ash can be seen up to $30 \%$.

- $\quad$ Due to the use of bagasse ash water absorption of concrete increases up to $18 \%$.

\section{REFERENCES}

1. Apiwaranuwat, A., Kitratporn, P. and Chuangcham, K. (2013) 'Use of Sugarcane Bagasse Ash as Raw Material in Production of Autoclaved Lightweight Concrete', Advanced Materials Research, 654, pp. 1242-1246. doi: 10.4028/www.scientific.net/AMR.652-654.1242.

2. Begum, R., Habib, A. and Mostafa, S. (2014) 'Effects of Rice Husk Ash on the Non Autoclaved Aerated Concrete Effects of Rice Husk Ash on the Non Autoclaved Aerated Concrete', International Journal of Engineering Innovation \& Research, 3(1), pp. 116-121.

3. Chen, Y. et al. (2017) 'A comprehensive study on the production of autoclaved aerated concrete: Effects of silica-lime-cement composition and autoclaving conditions', Construction and Building Materials. Elsevier Ltd, 153, pp. 622-629. doi: 10.1016/j.conbuildmat.2017.07.116.

4. Chindaprasirt, P., Sujumnongtokul, P. and Posi, P. (2019) 'Durability and Mechanical Properties of Pavement Concrete Containing Bagasse Ash', Materials Today: Proceedings. Elsevier Ltd., 17, pp. 1612-1626. doi: 10.1016/j.matpr.2019.06.191.

5. Esmaily, H. and Nuranian, H. (2012) 'Non-autoclaved high strength cellular concrete from alkali activated slag', Construction and Building Materials. Elsevier Ltd, 26(1), pp. 200-206. doi: 10.1016/j.conbuildmat.2011.06.010.

6. Fudge, C., Fouad, F. and Klingner, R. (2019) Autoclaved aerated concrete, Developments in the Formulation and Reinforcement of Concrete. Elsevier LTD. doi: 10.1016/B978-0-08-102616-8.00015-0.

7. IS 10262:2019 (2019) 'Concrete Mix Proportioning — Guidelines', Indian Standard, (January).

8. IS 12269:1987 (1999) 'Specification for 53 grade ordinary portland cement', Indian Standard, (April 1988). 
9. IS 383: 2016 (2016) 'Coarse and fine aggregate for concrete - specification (third revision)', Indian Standard, third edit(January).

10. IS 456:2000 (2000) 'Plain and Reinforced Concrete - Code of Practice', Indian Standard, (July).

11. IS 516:1959 (1959) 'Methods of Tests for Strength of Concrete', Indian Standard.

12. IS 5816:1999 (1999) 'Splitting Tensile Strength of Concrete- Method of Test', Indian Standard.

13. Kunchariyakun, K., Asavapisit, S. and Sinyoung, S. (2018) 'Influence of partial sand replacement by black rice husk ash and bagasse ash on properties of autoclaved aerated concrete under different temperatures and times', Construction and Building Materials. Elsevier Ltd, 173, pp. 220-227. doi: 10.1016/j.conbuildmat.2018.04.043.

14. Modani, P. O. and Vyawahare, M. R. (2013) 'Utilization of Bagasse Ash as a Partial Replacement of Fine Aggregate in Concrete', Procedia Engineering. Elsevier B.V., 51(NUiCONE 2012), pp. 25-29. doi: 10.1016/j.proeng.2013.01.007.

15. Munir, A. (2015) 'Utilization of palm oil fuel ash (POFA) in producing lightweight foamed concrete for non-structural building material', Procedia Engineering. Elsevier B.V., 125, pp. 739-746. doi: 10.1016/j.proeng.2015.11.119.

16. Patil, S. C. et al. (2017) 'Partially Replacement of Cement by Bagasse Ash', International Journal for Research in Applied Science \& Engineering Technology, 5(5), pp. 1582-1587.

17. Pavithra, N. et al. (2019) 'A Study on Compressive Strength of Concrete with Bagasse Ash as Supplementary Cementitious Material on Various Curing Methods', International Research Journal of Engineering and Technology (IRJET), 06(06), pp. 545-548.

18. Shrivastava, A. and Tiwari, P. A. (2017) 'Non Autoclaved Aerated Concrete (NAAC) Blocks: An Alternative Building Construction Material', International Journal for Research in Applied Science \& Engineering Technology (IJRASET), 5(8), pp. 808-812.

19. Sood, V., Negi, S. K. and Suman, B. M. (2019) 'Effect of Admixtures on the Thermo-Physical Properties of Non Autoclaved Light Weight Block Using Marble Dust', Key Engineering Materials, 801, pp. 365-370. doi: 10.4028/www.scientific.net/KEM.801.365.

20. Sundaravadivel, D. (2018) 'Recent Studies of Sugarcane Bagasse Ash in Concrete and Mortar- A Review', International Journal of Engineering Research \& Technology (IJERT), 7(04), pp. 306-312.

21. Ulykbanov, A. et al. (2019) 'Performance-based model to predict thermal conductivity of non-autoclaved aerated concrete through linearization approach', Construction and Building Materials. Elsevier Ltd, 196, pp. 555-563. doi: 10.1016/j.conbuildmat.2018.11.147.

22. Wang, C. et al. (2018) 'Utilization of oil-based drilling cuttings pyrolysis residues of shale gas for the preparation of nonautoclaved aerated concrete', Construction and Building Materials. Elsevier Ltd, 162, pp. 359-368. doi: 10.1016/j.conbuildmat.2017.11.151.

23. Xia, Y., Yan, Y. and Hu, Z. (2013) 'Utilization of circulating fluidized bed fly ash in preparing non-autoclaved aerated concrete production', Construction and Building Materials. Elsevier Ltd, 47, pp. 1461-1467. doi: 10.1016/j.conbuildmat.2013.06.033.

24. Yang, L., Yan, Y. and Hu, Z. (2013) 'Utilization of phosphogypsum for the preparation of non-autoclaved aerated concrete', Construction and Building Materials. Elsevier Ltd, 44, pp. 600-606. doi: 10.1016/j.conbuildmat.2013.03.070.

25. Singh, Saurabh Kumar, et al. "A Review on Effect of Mineral Admixture on Self Compacting Concrete." International Journal of Civil Engineering (IJCE) 3.3 (2014):79-90. 
26. George, Raiza Susan, and Nivin Philip. "A Review on Stress Block Parameters of High Performance Concrete." International Journal of Civil Engineering (IJCE) 5.6 (2016):25-32

27. Prasanna, SC, and T. Tamil Selvan. "Preparation of AL6061-SIC-Bagasse Ash Mmcs by using Stir Casting Method and Evaluation Microstructural, Mechanical Properties and Numerical Analysis." International Journal of Mechanical and Production Engineering Research and Development (IJMPERD) 8.2 (2018):677-682

28. Singh, Devinder., and Jaspal. Singh. "Use of agrowaste in concrete construction." International Journal of Environment, Ecology, Family and Urban Studies (IJEEFUS) 6.1 (2016): 119-130. 